
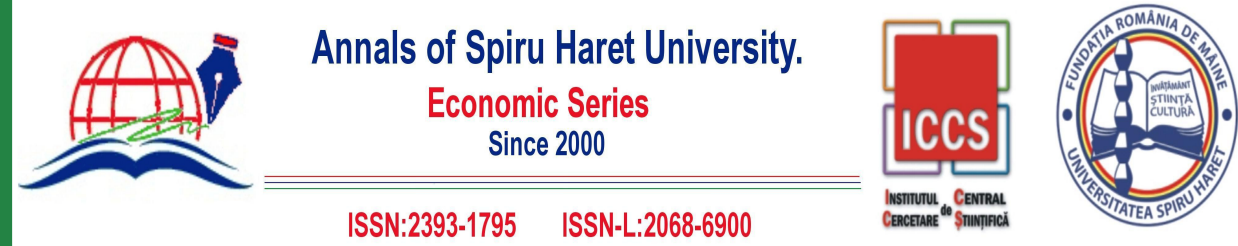

Issue 3/2019

\title{
THE EFFECTS OF LABOUR COSTS REDUCTION ON FOREIGN INVESTMENT IN ROMANIA
}

\author{
Adina TRANDAFIR ${ }^{1}$ \\ ${ }^{1}$ Spiru Haret University, Faculty of Law and Economics, Bucharest, \\ Romania, Email: adina.trandafir@spiruharet.ro
}

How to cite: TRANDAFIR, A. (2019). "The Effects of Labour Costs Reduction on Foreign Investment in Romania." Annals of Spiru Haret University. Economic Series, 19(3), 129-138, doi: https://doi.org/10.26458/1938

\begin{abstract}
This article addresses the issue of changes in tax legislation in our country over the last 20 months, in view of the effect they have on the level of foreign investment. The article presents, besides the actual legislative changes and the evolution registered in this period by foreign investments, also the fiscal pressure in the field of contributions, VAT and corporate income tax. The paper presents an econometric analysis that seeks to highlight the impact of the fiscal pressure of the above mentioned taxes on the FDI level recorded in Romania between January 2017 and August 2018.
\end{abstract}

Keywords: foreign direct investment; tax legislation; VAT; corporate income tax; contributions.

JEL Classification: $\mathrm{H} 21, \mathrm{H} 32$

\section{Introduction}

Addressing the issue of tax policy at microeconomic level, it is not to be neglected the very important role that taxation has in the life of business. It influences the legal form of organizing a business, choosing the location of the activities, the evolution of its activity and, last but not least, the results obtained. Managing effectively the economic and financial resources of a business means also 

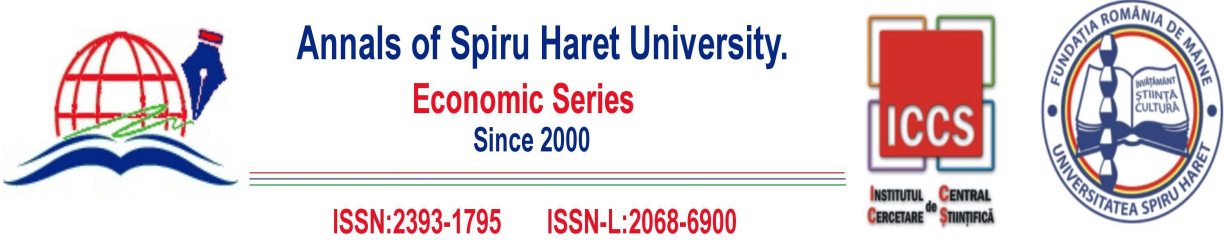

\section{Issue 3/2019}

taking into account the fiscal dimension of the activities. On the basis of the financial analysis, from the synthesis documents, it is possible to establish the past performance and estimate the, likely future, risk and fiscal effectiveness.

At a macroeconomic level, all governments are making efforts to attract FDI, which can generate new jobs, bring new technologies, and generally promote growth and employment. With these potential benefits, legislators are reviewing tax laws to ensure they are attractive to foreign investors.

The relevant literature has established that there is a link between FDI and different tax categories. De Mooij and Ederveen (2008) pay special attention to international investment, analysing the marginal elasticity of the tax base for corporate income tax. Becker, J. et al. (2012) analysed quantitatively and qualitatively the effects of corporate income tax on FDI.

Egger and Radulescu (2008) present in their work the impact of the labour tax on the establishment of foreign affiliates in a jurisdiction. Hale A. and Ahmet B. Y. (2017) analysed the relationship between indirect taxes and FDI in the case of Turkey in different sectors of activity.

Hebous S. et al. (2010) have estimated the impacts of differences in international tax rates on the probability of choosing a location for an affiliate of a multinational firm, making distinction between the tax sensitivity of Greenfield and M\&A investments.

This article aims to analyse the influence of legislative changes both in the field of contributions, direct taxes and indirect taxes on the level of FDI in Romania and it is structured in three parts: the first subchapter presents the legislative amendments from the last period in our country, the second part analyses from the econometric point of view the influence of the fiscal pressure of the aforementioned taxes on FDI, and the last part presents the conclusions and the limits of this research, as well as the directions to be followed by our country to become more attractive in terms of tax.

\section{Tax Changes in Romania and Their Effect on the Business Environment}

Amendments to tax legislation in Romania have been numerous lately and have affected all categories of taxpayers, reducing the competitiveness of our country in terms of taxation. Among the modifications made, we will enumerate below those with greater impact on the business environment. 


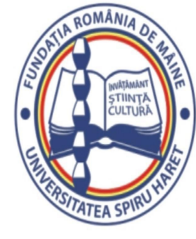

Issue 3/2019

\section{Changes of compulsory social contributions}

From the employer's point of view, with regard to social contributions, the fiscal pressure has dropped considerably, being transferred to the employee.

Since 2018, the number of compulsory social contributions has fallen from six, which was up to the end of 2017 at three (Government Ordinance 79/2017). Specifically, it is about the following mandatory contributions:

- contribution to pensions for normal working conditions, $25 \%$, which is entirely the responsibility of the employee;

- for special working conditions, the employer has an additional quota of $4 \%$ (i.e. $29 \%$, employee + employer) or $8 \%$ (i.e. $33 \%$ in total, employee + employer);

- health contribution (HC), 10\%, which is entirely the responsibility of the employee;

- Work Insurance Contributions (WIC), 2.25\%, which is entirely the responsibility of the employer.

Specifically, for employees working under normal conditions, contribution to social insurance (CSI) is $25 \%$, but for more difficult conditions of work, it is due to CSI of $29 \%$ or $33 \%$. In other words, the employer owes CSI, along with the employee, only when it comes to heavier working conditions.

Regarding Work Insurance Contributions (WIC), this includes the remaining four social contributions until last month. More specifically, the insurance contribution for work is made up of former contributions to unemployment, medical leave, occupational risks and salary claims $(2.25 \%)$.

Table 1. 2018 Compulsory Contributions in Romania

\begin{tabular}{|l|l|l|l|}
\hline Contribution & 2018 Rate & Owing & Paid by \\
\hline CSI & $\begin{array}{l}25 \% \text { (normal conditions) } \\
+4 \% \text { (difficult conditions) }\end{array}$ & $\begin{array}{l}\text { employee } \\
\text { employer }\end{array}$ & employer \\
\hline HC & $10 \%$ & employee & employer \\
\hline WIC & $2,25 \%$ & employer & employer \\
\hline
\end{tabular}

Source: Processing of data available in Government Emergency Ordinance no. 79/2017 for amending and completing the Law no. 227/2015 regarding the Fiscal Code. 


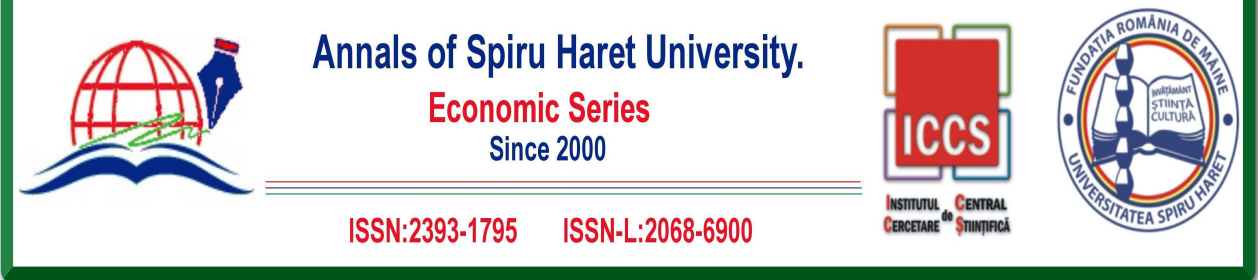

\section{Issue 3/2019}

Until the beginning of 2018, besides the contribution to unemployment, which was equally borne by the employee and the employer, contributions to medical leave, occupational risks and wage claims were paid only by the employer. From 2018 , the employer owes a minimum of $37.25 \%$ (normal working conditions) to an employee, compared to $39.25 \%$, the minimum total by the end of 2017 . For heavier work, the total is $41.25 \%$ or $45.25 \%$.

Only the employer calculates, retains and pays the social contributions. Employees have no obligation to do so, according to the legislation in our country. Until 31 December 2017, the total social contributions reached at least $39.25 \%$, but depending on the working conditions of an employee, the total could even reach $49.95 \%$.

This reduction in tax pressure also had other effects - at the labour market pressure, employers had to raise their gross wage by about $22.75 \%$, so that the net income of the employee did not decrease considerably. This measure was necessary despite the reduction of the income tax on wages from $16 \%$ to $10 \%$.

This measure does not imply an increase in wage costs for the employer, but only the uniform gross wage with total wage costs. There were also eliminated inequities on contributions as an equal percentage for all employees in Romania by giving up current ceilings on contributions. However, this alternative raises many questions about its constitutionality, namely whether a third party, the state in this case, may intervene in an ongoing bilateral contract.

\section{Changes in value added tax}

The Government of Romania adopted an Emergency Ordinance (GEO No.89 / 2018 ) to reduce VAT to $5 \%$ for services such as accommodation, restaurant and catering services, access to amusement parks and rental of camping grounds.

This change in the VAT area will generate a significant impact, mainly in tourism, recreation and the hospitality industry, represented by the HORECA sector (e.g. hotels, restaurants, and cafes). Romania has been experiencing an increased level of tax evasion in the tourism sector in the country in recent years. The measure to reduce the VAT rate from $9 \%$ to $5 \%$ for hospitality services should be an incentive to bring undeclared revenues to the surface and thus to pay VAT by economic agents. A direct effect of this measure for business in the field would be the potential reduction in gross fees, which would increase the occupancy rate of accommodation units, but not many people expect this VAT reduction to lead to a lowering of prices services. 


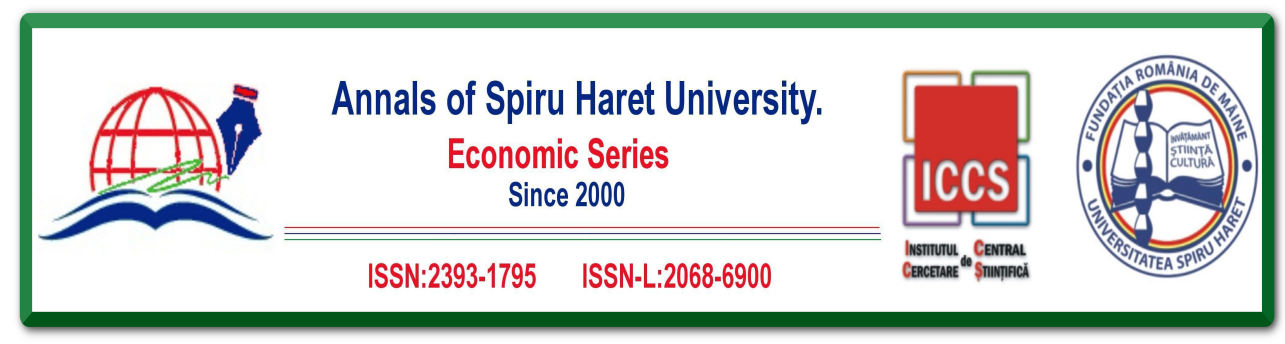

Issue 3/2019

According to the legal provisions, not all businesses will be able to benefit from the reduction in the VAT rate. An example of this is the food units that deliver food at home, but do not provide a space for consumption and do not offer related services (e.g. meal service). Therefore, the food ordered and delivered at home will be subject to $9 \%$ unlike the restaurant served.

Another change brought about by this ordinance is the reduction of the VAT rate from $19 \%$ to $5 \%$ for recreational services, i.e. access to amusement parks and recreational parks, as well as the use of sports facilities for practicing sport. The measure is welcome as Romania has a significant potential development in the area of recreational parks due to its natural relief and resources. In addition, these sectors have benefited from consistent investments in recent years, materialized in the appearance of several parks of fun and adventure in different parts of the country.

\section{Changes in the field of corporate tax}

The main change concerns the transposition of EU Directive 1164/2016 laying down rules against tax evasion practices which directly affect the functioning of the internal market. The thin capitalization rules will be abrogated and the new rule for limiting interest deductibility provided by EU Directive 1164/2016.

"Surplus borrowing costs" (including the difference between interest / currency and similar income) may be deducted within $10 \%$ of the reference value. Exit taxation is introduced for assets transferred by resident companies and / or permanent establishments as a result of business transfer, changes of residence or transfer / liquidation of permanent establishments.

The gain / loss on the transfer of assets will be calculated as the difference between the market value and the tax value of the assets. The profit tax rate $(16 \%)$ will apply separately to earnings, but the loss could be offset by gains on similar exit transactions (reporting period is 7 years).

In the case of exit taxation, it is specifically provided for the possibility to apply the payment order in accordance with the Fiscal Procedure Code. The tax value of assets transferred to Romania from other EU Member States (source state) will be the one used to calculate the exit tax in the source state, unless this value differs from market value.

\section{The Effects of Taxation on FDI in Romania}

The role that taxes and fees play in the decision to place a business in a particular jurisdiction is extremely important. It is true that not only the level of taxation 


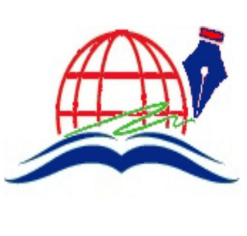

Annals of Spiru Haret University.

Economic Series

Since 2000
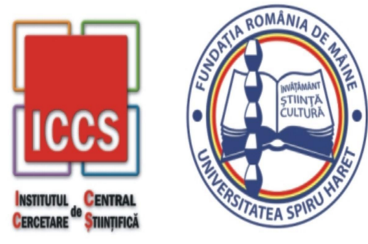

\section{Issue 3/2019}

matters, but it has a primordial role. The impact of taxation on the private business environment in Romania is very strong. The main obstacles are taxation and tax legislation in our country.

Lately, there has been a decrease in the tax burden in terms of tax work that falls on the employer and the number of taxes on labour (from six to three) and a decrease in VAT in certain sectors (tourism). At the same time, there was a downward trend in foreign direct investment.

The figure below shows the FDI evolution as a share of GDP, the fiscal pressure generated by social contributions, VAT and corporate tax at the macroeconomic level between January 2017 and August 2018.

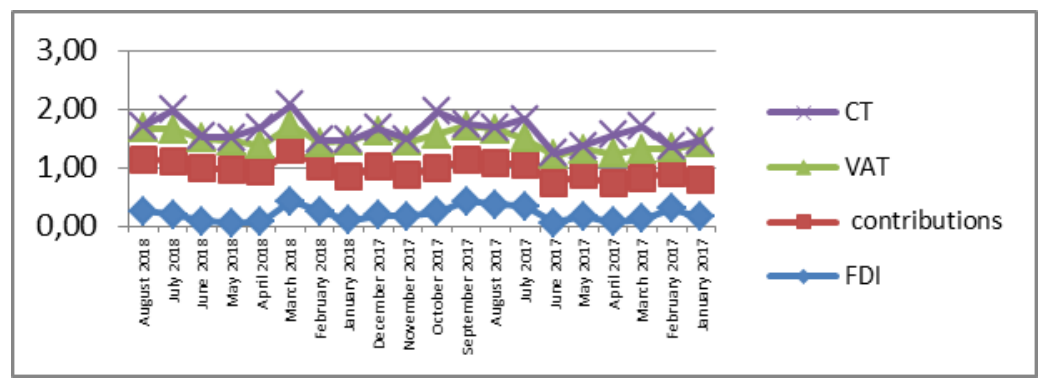

Fig. 1. FDI, Contributions, VAT and Corporate Income Tax Trend in Romania, January, 2017 - August 2018

Source: Own processing of data available on www.bnr.ro and www.mfinante.ro

According to data published by the National Bank of Romania (NBR) last year, foreign investments amounted to almost 4.8 billion Euros, up 6\% from the previous year (2016), and 7 months from 2018 barely reached 2.3 billion Euros. Moreover, in the NBR analysis, it is noted that Greenfield investments (from scratch, in new companies) have been almost non-existent in recent years, and the money brought by foreigners in the country concerned only the restructuring and development of the current business. In 2017, Greenfield and merger and acquisition (M \& A) investments followed the trend in recent years, recording a very low level. Thus, Greenfield investments contributed only 77 million Euros to the investment flow in equity shares of FDI enterprises, and mergers and acquisitions by 213 million Euros. The predominant share of capital flows in 2017 is provided by enterprise 134 


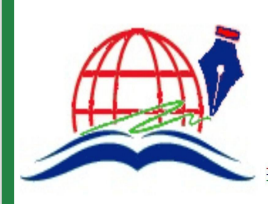

Annals of Spiru Haret University.

Economic Series

Since 2000
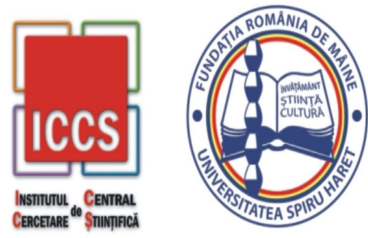

Issue 3/2019

restructuring of $€ 1.16$ billion, accounting for $52 \%$ of equity, and by business developments of $€ 787$ million, or $35 \%$ of holdings. (National Bank of Romania Report)

In order to show the role played recently by the "fiscal relaxation" on the level of FDI in our country, we started from the hypothesis that the decrease in fiscal pressure should have made our country more attractive to foreign investors. In this respect, we used an econometric model with a multi-linear regression equation of the form:

$$
F D I=\alpha+\beta \text { Contributions }+\gamma * V A T+\theta+\mathrm{CT}
$$

Where:

FDI - Foreign Direct Investment is the dependent variable;

Contributions, VAT and CT (Corporate Income Tax) - are the independent variables; $\alpha, \beta, \gamma, \vartheta$ - are the regression equation parameters.

Table 2. Regression Equation between FDI, Contributions, VAT and CT

\begin{tabular}{|c|c|c|c|c|}
\hline \multicolumn{5}{|c|}{ Dependent Variable: ISD } \\
\hline \multicolumn{5}{|c|}{ Method: Least Squares } \\
\hline \multicolumn{5}{|c|}{ Sample(adjusted): 2017:01 2018:08 } \\
\hline \multicolumn{5}{|c|}{ Included observations: 20 after adjusting endpoints } \\
\hline \multicolumn{5}{|c|}{ FDI $=\alpha+\beta *$ Contributions $+\gamma * \mathrm{VAT}+\vartheta * \mathrm{CT}$} \\
\hline & Coefficient & Std. Error & $\mathrm{t}$-Statistic & Prob. \\
\hline$\alpha$ & 0.379906 & 0.335251 & 1.133 .200 & 0.2738 \\
\hline$\beta$ & -0.142039 & 0.312137 & -0.455053 & 0.6552 \\
\hline$\gamma$ & -0.150061 & 0.446375 & -0.336177 & 0.7411 \\
\hline$\vartheta$ & 0.041630 & 0.209627 & 0.198591 & 0.8451 \\
\hline R-squared & 0.022056 & Mean dependent var & & 0.200455 \\
\hline Adjusted R-squared & 0.0161309 & S.D. dependent var & & 0.121353 \\
\hline S.E. of regression & 0.130775 & Akaike info criterion & & -1.053 .814 \\
\hline Sum squared resid & 0.273635 & Schwarz criterion & & -0.854668 \\
\hline Log likelihood & 1.453 .814 & Durbin-Watson stat & & 1.467 .940 \\
\hline
\end{tabular}

Source: Own processing of data available on www.bnr.ro and www.mfinante.ro 


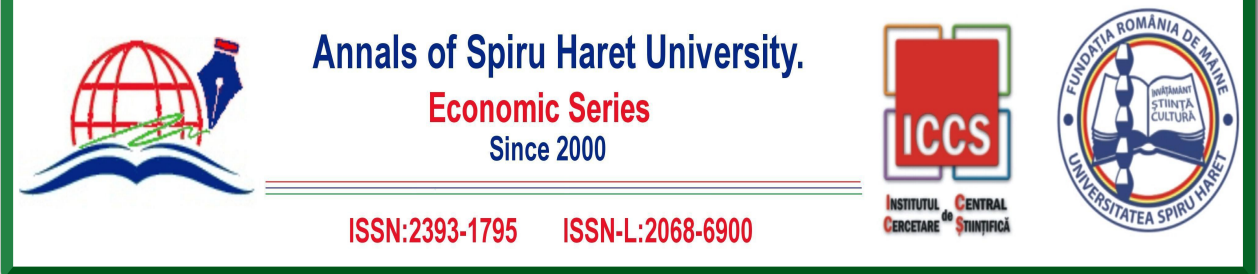

\section{Issue 3/2019}

In this case, we considered FDI as dependent variable and as independent variables the fiscal pressure of contributions, VAT and corporate income tax. This equation has to show the influence of legislative changes in the tax field on FDI in Romania in the last 20 months.

Using the least squares method in EViews, the following regression equation was obtained:

$$
\text { FDI }=0.379-0.142 * \text { Contributions }-0.150 * \mathrm{VAT}+0.042 * \mathrm{CT}
$$

According to this equation, the following results were obtained for Romania between January 2017 and August 2018: at a change with a percentage of the tax rate of the contributions, the FDI changed in the opposite direction by $0.142 \%$; to a change with a percentage of the VAT tax rate, FDI changed $0.150 \%$ as a share of GDP; to a change with a percentage of corporate tax rate, FDI has changed in the same way as $0.042 \%$.

The coefficient of determination for regression (R-squared) signifies the fact that $1.6 \%$ of the variation in FDI is explained by the modification of fiscal pressure in the contributions, VAT and corporate income tax fields. For a better accuracy of this study and to show how is influenced the level of ISD is necessary to take into account much more parameters, such as political and legislative stability, infrastructure, bureaucracy etc.

\section{Conclusion, Limitations and Future Research}

This article aims to analyze how they influenced legislative changes in the field of taxation, foreign direct investments in Romania during January 2017-August 2018. For this we used an econometric calculation, starting from the hypothesis that the level of taxation, which theoretically decreased in our country in the last period, should have made it more attractive to the sovereign investors. The statistics, however, show a level at least constant compared to the same period last year, and more than that, according to the Central Bank report, Greenfield and the mergers and acquisitions ( $\mathrm{M} \& \mathrm{~A}$ ) investments had a very low level.

The results of the econometric calculation show that during this period, with a one-percent decrease in the fiscal pressure of the contributions, the FDI increased by $0.14 \%$, a $1 \%$ decrease of the VAT fiscal pressure, FDI increased by $0.15 \%$, and a 


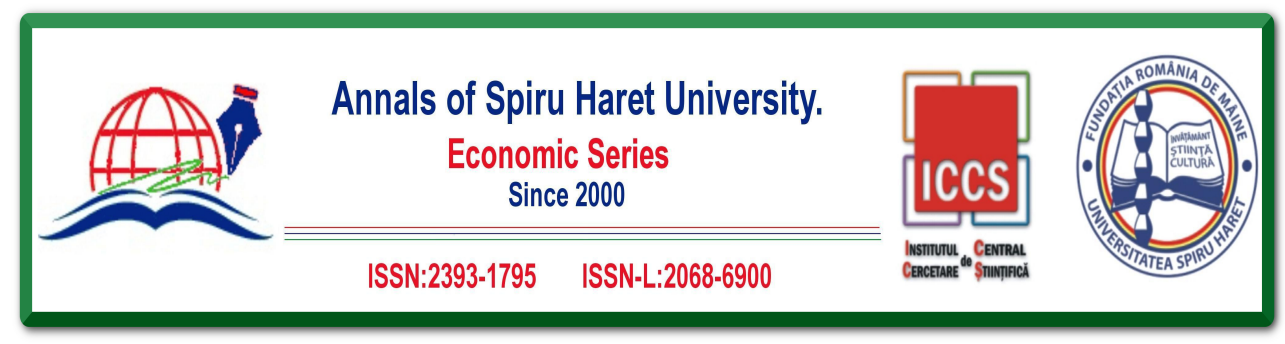

Issue 3/2019

change with a percentage of corporate tax rates, FDI changed in the same way as $0.042 \%$. These results lead us to the following conclusions:

1. Legislative changes in the tax area did not have the expected impact on foreign investors.

2. Legislative and political instability in our country has a greater impact on the investment decision.

3. According to the 2017-2018 Global Competitiveness Report, the global index of national competitiveness - defined as a set of institutions, policies and factors that determine the level of productivity, of Romania was the same as that of Georgia, 4.28 (p. 11), occupying the 68th place of 137 economies and being down 6 positions compared to the previous period. This and the results of the econometric calculation in this article demonstrate that the taxation does not have such a big impact on the decision to place an investment.

In order to attract investment, Romania needs to demonstrate consistency in fiscal, budgetary, investment policy, etc., to ensure adequate infrastructure and, above all, to take steps to increase confidence in public institutions.

As a result, the limits of this study refer to the failure to take into account several categories of parameters that influence the level and location of the investments.

\section{References}

[1] Becker, J., Fuest, C., \& Riedel, N. (2012). "Corporate Tax Effects on the Quality and Quantity of FDI." European Economic Review, 56(8), 1495-1511. doi: https://doi.org/10.1016/j.euroecorev.2012.07.001

[2] De Mooij \& Ederveen (2008), "Corporate Tax Elasticities: A Reader's Guide to Empirical Findings," Oxford Review of Economic Policy, 24(4), 680-697. Doi: https://doi.org/10.1093/oxrep/grn033

[3] Egger, P., \& Radulescu D., M. (2008). "Labour Taxation and Foreign Direct Investment." CESifo Working Paper, 2309 (May 2008), Available at https://ideas.repec.org/p/ces/ceswps/2309.html

[4] EU Directive 2016/1164, EU Official Journal no.193/19.07. 2016.

[5] Global Economic Forum, 2017-2018 Global Competitiveness Report, Available at https://www.weforum.org/reports/the-global-competitiveness-report-2017-2018

[6] Hale, A., and Ahmet, B.Y. (2017). "FDI and Indirect Taxes - Sector Approach: The Case of Turkey," International Journal of Economics and Financial Issues, 7(5), 112118. Available at: https://www.econjournals.com/index.php/ijefi/article/view/5235/pdf 

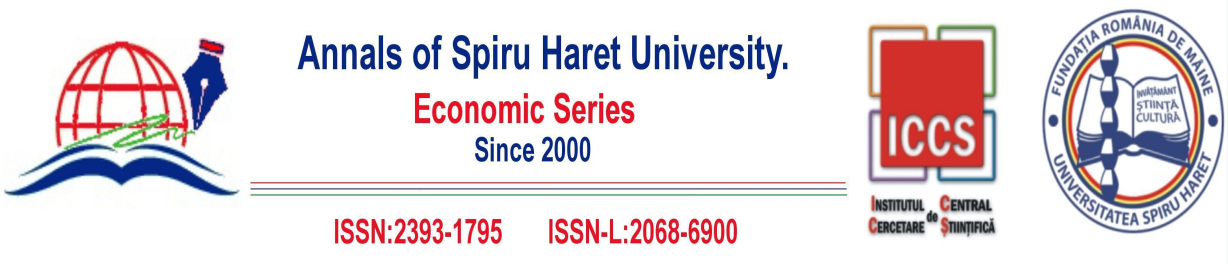

\section{Issue 3/2019}

[7] Hebous S., Ruf M., and Weichenrieder A. (2010). "The Effects of Taxation on the Location Decision of Multinational Firms: M\&A vs. Greenfield Investments, CESifo Working Paper Series, 3076. Available at: www.CESifo-group.org/wp

[8] Ordonanța de urgență a Guvernului nr. 79/2017 pentru modificarea și completarea Legii nr. 227/2015 privind Codul fiscal (Government Emergency Ordinance no. 79/2017 for amending and completing the Law no. 227/2015 regarding the Fiscal Code), Official Journal no. 885/10.11.2017

[9] Ordonanta Guvernului nr. 4/2017 (Government Ordinance no. 4/2017), Official Journal no. 598/25.07.2017

[10] Ordonanța de urgență a Guvernului nr.89/2018 privind unele măsuri fiscal-bugetare şi pentru modificarea şi completarea unor acte normative (Government Emergency Ordinance no. no.89 / 2018 regarding some fiscal-budgetary measures and for amending and supplementing some normative acts) Official Journal 854/09.10.2018

[11] Raport BNR - Investitiile straine directe in Romania 2017-2018 (2017-2018 NBR Report - Foreign Direct Investments in Romania), Available at http://www.bnr.ro/PublicationDocuments.aspx?icid=9403

[12] www.bnr.ro

[13] www.mfinante.ro 